\title{
Stress in Parents of Newborns in a Neonatal Intensive Care Unito
}

\author{
Estresse em pais de recém-nascidos em uma Unidade de Terapia Intensiva Neonatal \\ Estrés en padres de recién nacidos en una Unidad de Terapia Intensiva Neonatal
}

Jaquiele Jaciara Kegler ${ }^{1}$ Eliane Tatsch Neves ${ }^{1}(\mathbb{C})$ Augusto Maciel da Silva ${ }^{1}$ Leonardo Bigolin Jantsch ${ }^{1}$ Caren da Silva Bertoldo ${ }^{1}$ Júlia Heinz da Silva ${ }^{1}$

1. Universidade Federal de Santa Maria. Santa Maria, RS, Brasil.
Corresponding author: Jaquiele Jaciara Kegler. E-mail: jake_kegler93@hotmail.com

Submitted on $06 / 13 / 2018$. Accepted on 10/22/2018.

DOI: 10.1590/2177-9465-EAN-2018-0178

\section{Abstract}

Objective: To identify the level of stress and the most stressful situations for the parents of newborns hospitalized in a Neonatal Intensive Care Unit. Methods: A descriptive study, with a quantitative approach, performed with parents of newborns admitted to the Neonatal Intensive Care Unit. For the data collection, the Brazilian version of the Parental Stress Scale: Neonatal Intensive Care Unit (PSS: NICU) was used. The analysis was performed using descriptive statistics. Results: The change in the role of mother/father was the subscale in which the highest level of stress was obtained (mean=3.49) and the items considered more stressful in this subscale were "Separated from my baby" (mean=4.00) and "Feeling helpless and unable to protect my baby from pain and painful procedures" (mean=3.78). Conclusion: Hospitalization of a child in a neonatal unit is a stressful experience for parents and there are situations that trigger higher levels of stress.

Keywords: Stress, Psychological; Parents; Intensive Care Units, Neonatal; Neonatal Nursing.

\section{Resumo}

Objetivo: Identificar o nível de estresse e as situações mais estressantes para os pais de recém-nascidos internados em uma Unidade de Terapia Intensiva Neonatal. Método: Estudo descritivo, com abordagem quantitativa, realizado com pais/mães de recém-nascidos internados em Unidade de Terapia Intensiva Neonatal. Para a coleta dos dados, utilizou-se a versão brasileira da Parental Stress Scale: Neonatal Intensive Care Unit (PSS: NICU). A análise foi realizada por meio da estatística descritiva. Resultados: A alteração no papel de mãe/pai foi a subescala em que se obteve o maior nível de estresse (média $=3,49)$ e os itens considerados mais estressantes nessa subescala foram "Estar separada(o) do meu bebê" (média=4,00) e "Sentir-se desamparada(o) e incapaz de proteger o meu bebê da dor e de procedimentos dolorosos" (média=3,78). Conclusão: A hospitalização de um filho em unidade neonatal é uma experiência estressante para os pais e existem situações que desencadeiam estresse em níveis mais elevados.

Palavras-chave: Estresse Psicológico; Pais; Unidades de Terapia Intensiva Neonatal; Enfermagem Neonatal.

\section{Resumen}

Objetivo: Identificar el nivel de estrés y las situaciones más estresantes para los padres de recién nacidos internados en una Unidad de Terapia Intensiva Neonatal. Método: Estudio descriptivo, con abordaje cuantitativo, realizado con padres/madres de recién nacidos internados en Unidad de Terapia Intensiva Neonatal. Para la recolección de los datos, se utilizó la versión brasileña de la Parental Stress Scale: Neonatal Intensive Care Unit (PSS: NICU). El análisis fue realizado por medio de la estadística descriptiva. Resultados: La alteración en el papel de madre/padre fue la subescala en que se obtuvo el mayor nivel de estrés (promedio=3,49) y los ítems considerados más estresantes en esta subescala fueron "Estar separada(o) de $\mathrm{m}$ bebé" (promedio=4,00) y "Sentirse desamparada y incapaz de proteger a mi bebé del dolor y de los procedimientos dolorosos" (promedio=3,78). Conclusión: La hospitalización de un hijo en unidad neonatal es una experiencia estresante para los padres y hay situaciones que desencadenan niveles más elevados de estrés.

Palabras clave: Estrés Psicológico; Padres; Unidades de Cuidado Intensivo Neonatal; Enfermería Neonatal. 


\section{INTRODUCTION}

Technological and scientific knowledge advances enabled great change on neonatal care, contributing to premature newborns (NB), until then considered unviable, become the main clients assisted in Neonatal Intensive Care Units (NICU). ${ }^{1}$ Currently, it's estimated the birth of about 15 million premature babies in the world. ${ }^{2}$ In Brazil, according to data from Ministry of Health, in the year of $2015,10.8 \%$ of births were premature NB. In this same period, in the state of Rio Grande do Sul, premature births represented $11.4 \%$ of the total births. ${ }^{3}$

Premature NB is extremely vulnerable to the innumerous clinical aspects and because of this, frequently, needs intensive care. Hospitalization of a child in NICU is a stressing experience for parents and, when associated with prematurity, the level of stress tends to be bigger. This is due to, probably, the possibilities of him not survive and the risk of complications long term. ${ }^{4}$

There are aspects that can unveil stress in parents in NICU, once the NB is surrounded of unknown sounds, constant lights e a great number of people in this environment; and he/she also needs painful procedures. ${ }^{5}$ Beyond that, the parents find themselves with a small and fragile baby, a very different image of the expectations during pregnancy in which they idealized a big and healthy child. ${ }^{5}$

The stress experienced in the NICU can result on the emergence of a depressive state, anxiety disorders, fatigue, and sleeping disorders, that can follow parents even after hospital discharge, compromising the promotion of bond between parents and children and the newborn development. ${ }^{6} \mathrm{~A}$ study evidenced that social, behavioral and functional development of the pre-term is influenced by parents' stress and maternal depressive symptoms. ${ }^{7}$

With the aim to identify and assist on facing situations that unveil stress in parents in NICU and, this way, to favor the construction of bond between parents and children is what Souza $^{8}$ translated, adapted and validated, in 2009, a Parental Stress Scale: Neonatal Intensive Care Unit (PSS: NICU) to Brazilian population. She used as the base the Miles, Funk and Carlson $^{9}$ version that was created in the English language in 1993, with the aim to evaluate stress experienced by parents of NB in neonatal intensive care.

This way, considering negative repercussions of a child hospitalization in NICU about establishing a bond, parents' physical and mental health, and NB's development afterward, this study is justified to identify stressors of parents present in NICU, so that, later, strategies can be implemented by health professionals to minimize them. Still, from a search in national and international literature, it was identified the incipience of studies in the Brazilian scenery that used PSS: NICU as an instrument to identify these stressors.
Against the foregoing, we questioned: what's the level of stress of parents and situations considered more stressing for them in a Neonatal Intensive Care Unit? From this question, this study aims: to identify the level of stress and stressing situations for parents of newborns admitted in a Neonatal Intensive Care Unit.

\section{METHOD}

Descriptive study with a quantitative approach developed in the NICU of a public hospital of the central region of Rio Grande do Sul. The NICU has 23 beds, ten reserved for high-risk NB, eight for intermediary risk and five for kangaroo care.

Parents (father and/or mother) of hospitalized NB in the NICU participated in the study. Inclusion criteria were the father/mother must have visited his/her child at least three times between data collection and the NB must have to be hospitalized in the NICU for at least five days. As exclusion criteria included father/mother of NB who were admitted directly to kangaroo unit

Data were collected between January and August of 2017 by this article's first author, assisted by a trained nursing student (fifth author), that had a scholarship for scientific initiation in the referred period. We used an instrument for characterizing the participants, divided into two blocks - Block A - Sociodemographic profile of the father/mother and Block B - newborn's clinical profile - and PSS: NICU translated and validated to Brazilian population. ${ }^{8}$

Block A - Socio-demographic profile of the father/mother was composed by the variables: date of birth, sex, marital status, number of children, previous experience with an admission of a child in NICU, race/color of skin, schooling, occupation, religion and place of residence. To characterize income and basic sanitation conditions, we used a questionnaire from the Brazilian Association of Research Companies - ABEP.Block B - Newborn's clinical profile was constituted by the variables: date of birth, hospitalization unit, days of hospitalization, genre, birth weight, delivery, birth intercurrences, Apgar of the $1^{\text {st }}$ and $5^{\text {th }}$ minute, reason to hospitalization, breathing, intravenous and nutritional therapeutic, phototherapy use, congenital malformation, previous surgical procedure, sedation use, drain, special coverage and vesicle catheter.

PSS: NICU has 26 items, distributed in three subscales that measure the stress of parents relating with sounds and images, appearance and behavior of the baby and alteration of the role of father/mother. In a scale type Likert, with a score between 1 and 5, parents must indicate how stressing was the experience described in each item. Score "1" refers to not stressing, "2" to little stressing, " 3 " to moderately stressing, "4" to very stressing and " 5 " to extremely stressing. There is still the possibility of parents to answer "NA" to "it does not apply" if they did not go through the described experience. ${ }^{8}$ 
The search for participants was done every day except when we verified that there was not any possible father/mother that met inclusion criteria in the following day. When the participant met inclusion criteria, he was invited to participate in the study being the data collection done individually in rooms available in the NICU, guaranteeing privacy.

Initially, mediated by an interview done with the father/mother we filled Block A - Socio-demographic profile of the father/mother. Subsequently, PSS: NICU was delivered and filled by the father/ mother. In general, this fill happened at an average time of ten minutes. We highlight the scale was applied as an interview to non-alphabetized parents and to those who had some kind of visual limitation. As for block B - Newborn's clinical profile, we filled it with the medical records data obtained with the nursing staff.

Independent double typing of data was developed in the software Epi-info ${ }^{\circledR}$ (version 7.2.1). After verifying and correcting typing inconsistencies, the data were analyzed in the statistical program $R$ (version 3.4.2). ${ }^{10}$ To descriptive analysis, we used central and dispersion tendency measures and absolute and relative frequencies. PSS: NICU answers were analyzed according to the level of stress occurrence (Metric 1) that evaluates the stress level experienced in relation to other situations cited in the items. The denominator to obtain the average of each subscale is the number of items experienced by parents.

PSS: NICU reliability analysis was developed through Alpha Cronbach coefficient. We found 0.92 alpha to PSS: NICU. To analyze subscales, "Sounds and images" obtained the value of 0.77, "Baby's appearance and behavior" and "Attention on Mother/Father role" presented a 0.87 alpha. These values indicate a good internal consistency of data obtained in the present study.

The study was developed according to Resolution no 466, from December $12^{\text {th }}, 2012$, from the National Council of Health and approved by the Research Ethics Committee from the Federal University of Santa Maria in 12/14/2016 under the feedback number: 1.865 .348 ad Certification of Presentation for Ethical Appreciation (CAAE): 62641816.7.0000.5346. All participants signed a free consent form before data collection mediated by the reading of it. Instruments were applied to parents in a room in the unit that offered privacy.

\section{RESULTS}

\section{Characterization of Participants}

204 parents of NB admitted to the NICU participated in the study. These were in its majority, female ( $\mathrm{N}=127 ; 62.3 \%)$, with an average of age 28.5 years old ( $D P=7.6)$. They lived in a stable unit or with a partner $(\mathrm{N}=137 ; 67.2 \%)$, they had one child $(\mathrm{N}=93$; $45.6 \%)$, they white $(\mathrm{N}=125 ; 61.3 \%)$ and Catholic $(\mathrm{N}=72 ; 35.3 \%)$. We highlight that 12 parents were less than 18 years old in the moment of the data collection.
They have completed high school ( $\mathrm{N}=57 ; 27.9 \%)$, followed by incomplete elementary school $(\mathrm{N}=51 ; 25 \%)$. They belonged to the socio-economical extracts $\mathrm{C} 2(\mathrm{~N}=48 ; 23.5 \%)$ and $\mathrm{D}-\mathrm{E}(\mathrm{N}=48$; $23.5 \%$ ), which corresponds to an estimative of family income of $R \$ 1,446,24$ and $R \$ 639,78$, respectively. Most of the parents resided in the city of the study $(\mathrm{N}=110 ; 53.9 \%)$ and did not have any experience with the hospitalization of a child ( $N=176 ; 86.3 \%)$.

\section{Evaluation of stress levels of parents}

On Table 1 we describe averages obtained from answers of the items in the subscale PSS: NICU.

It was evidenced that the subscale that presented the lowest levels of stress was "Sounds and Images", with an average of 2.26. Average answers to the items of this subscale varied from 1.46 to 3.44 and situations pointed by parents as the most stressing ones were "To see a machine to breathe for your baby" (average=3.44) and "A sudden noise from monitors' alarms" (average=2.58). In the subscale "Baby's appearance and behavior" (average $=2.83$ ), averages varied from 1.57 to 3.53 , being the most stressing items "When my baby seemed to be experiencing pain" (average=3.53) and "When my baby seemed sad" (average $=3.45$ ) (Table 1 )

The subscale that presented the biggest level of stress was the "Alteration of the role of Mother/Father", with an average of 3.49. In this subscale, averages varied from 3.08 to 4.00 and items that presented the highest stress scores were "Being apart from my baby" (average=4.00) and "Feeling helpless and incapable of protecting my baby from pain and from painful procedures" (average $=3.78$ ), both considered very stressing. We obtained an average of 2.86 on the whole scale, considered moderately stressing (Table 1).

\section{DISCUSSION}

Parents of this study considered the subscale "Alteration in the Role of Mother/Father" as the most stressing (average=3.49), corroborating with studies developed in the United States ${ }^{6}$ (average=3.25), Spain ${ }^{11}$ (average=3.14) and Australia ${ }^{12}$ (average $=3.47$ ).

Superior stress levels were found in studies in Paraná ${ }^{13}$ and São Paulo, ${ }^{8}$ with averages 4.3 and 3.7 , respectively. The fact of the study developed in Paraná ${ }^{13}$ has found levels of stress very superior of this study and other, can be explained for it to be developed only with mothers. Which is confirmed by a study from Portugal, ${ }^{14}$ that identified that mothers presented a superior stress level (average $=4.1$ ) than fathers (average $=3.2$ ) in the subscale of alteration in the role of mother/father.

It is perceived that the alteration of the parental role was identified as the main cause of stress in NICU parents of several countries. This can be explained for these not being 
Table 1. Analysis of averages of parents' answers to items of PSS: NICU. Rio Grande do Sul, 2017

\begin{tabular}{|c|c|}
\hline PSS: NICU Items & Average \\
\hline Sounds and images & 2.26 \\
\hline 1. The presence of monitors and equipment & 2.03 \\
\hline 2. Constant noise from monitors and equipment & 2.18 \\
\hline 3. A sudden noise from monitors' alarms & 2.58 \\
\hline 4. Other sick babies in the room & 1.85 \\
\hline 5. The great number of people working in the unit & 1.46 \\
\hline 6. To see a machine to breathe for your baby & 3.44 \\
\hline Baby's appearance and behavior & 2.83 \\
\hline 1. Tubes and equipment in my baby or near him & 2.81 \\
\hline 2. Bruised areas, cuts or lesion in my baby & 3.22 \\
\hline 3. The normal color of my baby (for example: pale or yellow) & 2.64 \\
\hline 4. My baby's uncommon or abnormal breathing & 3.26 \\
\hline 5. My baby's small size & 2.20 \\
\hline 6. My baby's wrinkled appearance & 1.57 \\
\hline 7. To see needles and tubes in my baby & 3.21 \\
\hline 8. My babe being fed through the vein or a tube & 3.00 \\
\hline 9. When my baby seemed to be experiencing pain & 3.53 \\
\hline 10. When my baby seemed sad & 3.45 \\
\hline 11. My baby's flaccid and fragile appearance & 2.66 \\
\hline 12. My baby's agitated and unquiet movements & 2.75 \\
\hline 13. My baby not being able to cry like other babies & 2.43 \\
\hline Alteration in the role of the mother/father & 3.49 \\
\hline 1. Being apart from my baby & 4.00 \\
\hline 2. Not being the one to feed my baby & 3.43 \\
\hline 3. Not being able to care for my baby (for example: changing diapers, giving a bath) & 3.19 \\
\hline 4. Not being able to hold my baby when I want & 3.37 \\
\hline 5. Feeling helpless and being unable to protect my baby from pain and from painful procedures & 3.78 \\
\hline 6. Feeling unable to help my baby during this time & 3.61 \\
\hline 7. Not having the time of being alone with my baby & 3.08 \\
\hline Total & 2.86 \\
\hline
\end{tabular}

able to assume roles of father and mother facing their child hospitalization in these units, which generates frustration and makes they feel incapable for not being able to protect and care of their own child. ${ }^{14}$

These feelings are still more evident in mothers, ${ }^{13,14}$ due to them not being able to perform actions like breastfeeding, changing diapers, giving a bath, hugging, kissing and caressing the child while holding him. This makes the mother experience the function loss, presenting, many times, difficulty in recognizing her own child, which impacts in the way the mother relates with him, which can compromise the child's development afterwards. ${ }^{5}$
In a study developed in a NICU in the city of Palmas/TO, ${ }^{15}$ it was perceived that when mothers were included by health professionals in the care of the child they felt like taking the mother role effectively and, that made mothers feel more competent to care for their children.

In this sense, NICU professionals can assist in the process of constructing maternal autonomy. For that, initially, in a welcoming and available manner, professionals can demonstrate and guide mothers about developed care, then, to encourage her to perform them and help her until she feels confident to develop care of children, having the professional only for supervision. ${ }^{16}$ 
In relation to the items of the subscale "Alteration in the Role of Mother/Father", parents considered as the most stressing fact to be apart from their children and feeling helpless and incapable of protecting them from pain and from painful procedures. In a multi-centric study, ${ }^{17}$ developed in Argentina, Chile, Paraguay, and Peru, it was found that being apart from the child, followed by not being able to feed him and not being able to protect him from pain and painful procedures constituted the most stressing aspects for parents. In contrast, not being able to feed the child and not knowing how to help him during hospitalization in the NICU were considered the most stressing situations in this subscale by Indian mothers. ${ }^{18}$

The subscale that presented the lowest stress level was "Sounds and Images" (average=2.26), which is in consonance with other studies developed in countries as the United States $^{6}$ (average $=2.37$ ), Spain ${ }^{11}$ (average $\left.=2.25\right)$, Australia ${ }^{12}$ (average $=2.38$ ) and $\mathrm{Brazil}^{8}$ (average $=2.3$ ). The need of using a respirator by the child and the sudden noise from monitors' alarms were considered the most stressing situations in the subscale sounds and images by fathers and mothers of a NICU in Australia, ${ }^{12}$ as it was observed in this study.

About the subscale "Baby's appearance and behavior" (average $=2.83$ ) we found similar findings in other studies, with averages that varied from 2.85 to 3.09 , indicating a moderate stress level. ${ }^{6,8,11,12}$ Finding that differ from the one found in a study developed with Indian mothers, once these presented an average of 4.10 in this subscale, which is considered very stressing. ${ }^{18}$

The most stressing items in this subscale were "When my baby seemed to be experiencing pain" and "When my baby seemed sad", which was confirmed in a study from Australia. ${ }^{12}$ This finding corroborates with the study developed in Palmas$\mathrm{TO},{ }^{15}$ when it evidenced that frequent painful procedures in the NB generate great stress and suffering in the mothers, even though these recognize that these are necessary to guarantee the health of their children.

In the whole scale, parents presented an average of 2.86, corroborating with results from other studies that also identified a general level considered moderately stressing. ${ }^{6,8,12,17}$

This study's findings showed us the need to implement strategies in the NICU in order to minimize parents' suffering and favor the parental role. This way, independently of the strategy, caring for the NB must include caring for the family, meeting presupposes from Family-Centered Care. NICU professionals need to establish forms of communication and interaction with the parent, promoting their participation in the care, guiding them and incentivizing them to touch their children, being this an attribution of the whole team involved in caring for the newborn and not only the nurse. ${ }^{19}$

The study presents as limitations the fact it was only developed in one NICU and not including all parents of NB admitted in the unit in the period of data collection. We highlight the need for new studies that seek the identification of effective and viable intervention to be developed in the NICU to reduce parents' stress.

\section{CONCLUSION}

From the application of PSS NICU, we could perceive that this showed itself as a reliable instrument to evaluate stressors present in the NICU, evidencing by indicative values of a good internal consistency, obtained from Alpha Cronbach. Still, we conclude that "Alteration in the role of mother/father" was the subscale that it was identified the greater stress level from parents, followed by "Baby's appearance and behavior" and "Sounds and Images".

Situations considered by parents as the most stressing ones in the subscale "Alteration in the role of mother/father" were "Being apart from my baby" and "Feeling helpless and incapable of protecting my baby from pain and painful procedures". On "Baby's appearance and behavior", the most stressing situations were "When my baby seemed to be experiencing pain" and "When my baby seemed sad" and in the subscale "Sounds and Images", they were "To see a machine breathe for my baby" and "A sudden noise from monitors' alarms". Parents considered the general experience of having a child admitted in the NICU as moderately stressing.

The present study's results contribute to planning actions by NICU professionals that can minimize situations considered by parents as the most stressing ones, especially, those that involve parental role. We believe that some actions can be used to lower parents' pain and parental development, such as parents' involvement in caring for the NB, giving clear and precise information, development of a group of parents, educational material about norms and daily care in the NICU and participation of parents in painful procedures. Beyond that, we believe that this study enabled also the reflection of NICU professionals about their care practices as well as it contributed to amplifying the validation of the PSS: NICU in the NICU context in Rio Grande do Sul.

\section{Financial support}

Scholarship of Master Nursing Program provided by the Coordenação de Aperfeiçoamento de Pessoal de Nível Superior Brasil (CAPES), funding Code number 001, to the first author.

\section{REFERENCES}

1. Lima SS, Silva SM, Avila PES, Nicolau MV, Neves PFM. Aspectos clínicos de recém-nascidos admitidos em Unidade de Terapia Intensiva de hospital de referência da Região Norte do Brasil. ABCS Health Sci [Internet]. 2015; [cited 2016 Sep 22]; 40(2):62-8. Available from: https:// www.portalnepas.org.br/abcshs/article/viewFile/732/672

2. World Health Organization - WHO. Preterm birth. Fact sheet $\mathrm{N}^{\circ} 363$ [Internet]. 2017; [cited 2018 Jan 10]. Available from: http://www.who. int/mediacentre/factsheets/fs363/en/ 
3. Ministério da Saúde (BR). DATASUS. Informações de Saúde (TABNET). Estatísticas Vitais. Nascidos Vivos - 1994 a 2016. Brasília (DF): Ministério da Saúde [Internet]; 2015 [cited 2018 Jan 10]. Available from: http://www2.datasus.gov.br/DATASUS/index.php?area $=0205 \&$ id $=693$ $6 \& \mathrm{VObj}=\mathrm{http}: / /$ tabnet.datasus.gov.br/cgi/deftohtm.exe?sinasc/cnv/nv

4. Schappin R, Wijnroks L, Uniken Venema MM, Jongmans MJ. Rethinking stress in parents of preterm infants: a meta-analysis. PLoS One [Internet]. 2013; [cited 2016 Sep 24]; 8(2):e54992. Available from: https://www.ncbi.nlm.nih.gov/pubmed/23405105

5. Cartaxo LS, Torquato JA, Agra G, Fernandes MA, Platel ICS, Freire MEM. Vivência de mães na unidade de terapia intensiva neonatal. Rev Enferm UERJ [Internet]. 2014 Jul/Aug; [cited 2016 Sep 22];22(4):551-7. Available from: http://www.facenf.uerj.br/v22n4/v22n4a19.pdf

6. Busse M, Stromgren K, Thorngate L, Thomas KA. Parents' responses to stress in the neonatal intensive care unit. Crit Care Nurse [Internet]. 2013 Aug; [cited 2016 Sep 23]; 33(4):52-9. Available from: https://www. ncbi.nlm.nih.gov/pubmed/23908169

7. Huhtala M, Korja R, Lehtonen L, Haataja L, Lapinleimu H, Rautava P; PIPARI Study Group. Associations between parental psychological wellbeing and socio-emotional development in 5-year-old preterm children. Early Hum Dev [Internet]. 2014 Mar; [cited 2016 Sep 22]; 90(3):119-24. Available from: https://www.ncbi.nlm.nih.gov/pubmed/24418104

8. Souza SR, Dupas G, Balieiro MMFG. Adaptação cultural e validação para a língua portuguesa da Parental Stress Scale: Neonatal Intensive Care Unit (PSS:NICU). Acta Paul Enferm [Internet]. 2012; [cited 2016 Sep 20]; 25(2):171-6. Available from: http://www.scielo.br/pdf/ape/ v25n2/a03v25n2.pdf

9. Miles MS, Funk SG, Carlson J. Parental Stressor Scale: neonatal intensive care unit. Nurs Res [Internet] 1993 May/Jun;42(3):148-52. Available from: https://www.ncbi.nlm.nih.gov/pubmed/8506163

10. R Core Team. R: A language and environment for statistical computing. Vienna: R Foundation for Statistical Computing [Internet]; 2017 [cited 2018 Jan 10]. Available from: https://www.R-project.org/

11. Sánchez-Veracruz MJ, Leal-Costa C, Pastor-Rodríguez JD, DíazAgea JL. Relación entre el grado de satisfacción y el nivel de estrés identificado en padres y madres con hijos ingresados en una unidad de cuidado intensivo neonatal. Enferm Glob [Internet]. 2017 Jul; [cited 2018 Jan 16]; 16(47):270-80. Available from: http://revistas.um.es/ eglobal/article/viewFile/256061/213061
12. Turner $M$, Chur-Hansen $A$, Winefield $H$, Stanners $M$. The assessment of parental stress and support in the neonatal intensive care unit using the Parent Stress Scale - Neonatal Intensive Care Unit. Women Birth [Internet]. 2015 Sep; [cited 2018 Jan 24]; 28(3):252-8. Available from: https://www.ncbi.nlm.nih.gov/pubmed/25956972

13. Fernandes JN, Viera CS, Guimarães ATB, Toso BRGO, Machineski GG. Avaliação do nível estresse de mães de pré-termo em hospital universitário. Ciênc Cuid Saúde [Internet]. 2015 Oct/Dec; [cited 2018 Jan 26]; 14(4):1471-9. Available from: http://www.periodicos.uem.br/ ojs/index.php/CiencCuidSaude/article/view/27149/16618

14. Baía I, Amorim M, Silva S, Kelly-Irving M, de Freitas C, Alves E. Parenting very preterm infants and stress in Neonatal Intensive Care Units. Early Hum Dev [Internet]. 2016 Oct; [cited 2016 Sep 22]; 101:3-9. Available from: https://www.ncbi.nlm.nih.gov/pubmed/27393922

15. Santos LF, Souza IA, Mutti CF, Santos NSS, Oliveira LMAC. Forças que interferem na maternagem em unidade de terapia intensiva neonatal. Texto Contexto Enferm [Internet]. 2017 Sep; [cited 2018 Jan 25]; 26(3):e1260016. Available from: http://www.scielo.br/pdf/tce/ v26n3/0104-0707-tce-26-03-e1260016.pdf

16. Veronez M, Borghesan NAB, Corrêa DAM, Higarashi IH. Vivência de mães de bebês prematuros do nascimento a alta: notas de diários de campo. Rev Gaúch Enferm [Internet]. 2017 Jul; [cited 2018 Jan 20]; 38(2):e60911. Available from: http://www.scielo.br/pdf/rgenf/ v38n2/0102-6933-rgenf-1983-144720170260911.pdf

17. Wormald F, Tapia JL, Torres G, Cánepa P, González MA, Rodríguez $D$, et al. Estrés en padres de recién nacidos prematuros de muy bajo peso hospitalizados en unidades de cuidados intensivos neonatales. Estudio multicéntrico. Arch Argent Pediatr [Internet]. 2015 Aug; [cited 2018 Jan 26]; 113(4):303-9. Available from: http://www.scielo.org.ar/ pdf/aap/v113n4/v113n4a05.pdf

18. Chourasia N, Surianarayanan P, Adhisivam B, Vishnu Bhat B. NICU admissions and maternal stress levels. Indian J Pediatr [Internet]. 2013 May; [cited 2018 Jan 15]; 80(5):380-4. Available from: https://www.ncbi. nlm.nih.gov/pubmed/23180413

19. Silva CC, Paula GR, Peixoto MKAV, Oliveira NES, Santos LF, Oliveira LMAC. Assistência de enfermagem a familiares de recém-nascidos em unidade de terapia intensiva neonatal: revisão integrativa. Ciênc Cuid Saúde [Internet]. 2013 Oct/Dec; [citado 2016 Sep 23]; 12(4):80412. Available from: http://www.periodicos.uem.br/ojs/index.php/ CiencCuidSaude/article/view/22550/pdf_102

\footnotetext{
a Article extracted from Master's Thesis "Stressors of parents in a Neonatal Intensive Care Unit", presented to the Nursing Graduate Program, in the year of 2018, Universidade Federal de Santa Maria - UFSM, under the authorship of first author, supervisor by the second and co-supervisor by the third one.
} 